\title{
Krzysztof Boroda
}

Białystok

\section{Przeszłość przeliczników demograficznych dla szesnastowiecznych źródel podatkowych}

Wydając w 1883 roku pierwszy tom Polski XVI wieku pod względem geograficzno-statystycznym (tom XII serii Źródeł Dziejowych), otwierający cykl edycji rejestrów poborowych z drugiej połowy XVI wieku, Adolf Pawiński zapoczątkował ponad wszelką wątpliwość epokę statystyczną w polskiej historiografii. Wywołał przy tym kilka chyba wciąż niezakończonych dyskusji naukowych, i wyrządził kilka niezamierzonych - i w części nienaprawionych do dzisiaj - szkód. Paradoksalnie największą szkodą okazała się być sama edycja rejestrów. Pomijając brak stosowania przez wydawcę jednolitych zasad edycji, największym problemem okazała się być fatalna jakość odpisów sporządzonych przez współpracowników Pawińskiego, które ewidentnie nie były przez nikogo weryfikowane przed wydaniem drukiem. W przypadku niektórych z rejestrów skala opuszczeń zupełnie dyskwalifikuje przydatność edycji Pawińskiego do badań ${ }^{\text {. Główną }}$ przeszkodą uniemożliwiającą przeprowadzenie postulowanej przez niektórych badaczy reedycji rejestrów było przy tym - o ironio - to, że istniała już edycja Pawińskiego. Także postulowana przez Irenę Gieysztorową i Annę Żaboklicką edycja rejestrów dla samego Mazowsza w czterech przekrojach chronologicznych, mimo jego fizycznego przygotowania, nigdy nie została zrealizowana ${ }^{2}$. Dopiero w chwili obecnej, dzięki realizowanemu przez Pracownię Atlasu Historycznego

\footnotetext{
${ }^{1} \mathrm{Na}$ przykład w rejestrach z terenu Mazowsza czy też województwa krakowskiego mamy do czynienia ze świadomym pominięciem młynów czy też innych elementów infrastruktury przemysłowej, jak też regularnym opuszczaniem w przypadku rejestrów szlachty zagrodowej części wymienionych przy poszczególnych działach właścicieli.

${ }^{2}$ Irena Gieysztorowa, Anna Żaboklicka, Rejestry poborowe Mazowsza z XVI wieku, „Kwartalnik Historii Kultury Materialnej” 3, 1955, nr 2, s. 351.
} 
Polskiej Akademii Nauk projektowi Atlas Źródet i Materiałów z Dziejów Dawnej Polski $i^{3}$ mamy szansę doczekać się w niedalekiej przyszłości nowej, cyfrowej edycji rejestrów poborowych. Wśród wywołanych dyskusji dwie wypada uznać za najistotniejsze. Pierwsza wiązała się z podjętą przez Pawińskiego próbą obliczenia liczby ludności Królestwa Polskiego dla schyłku XVI wieku i dotyczyła przede wszystkim przeliczników demograficznych wykorzystywanych $\mathrm{w}$ analizie danych zawartych w rejestrach podatkowych. Edycję każdego kolejnego zbioru źródeł podatkowych dla poszczególnych dzielnic Królestwa Polskiego wydawcy (Adolf Pawiński, a po nim kontynuator jego dzieła, Aleksander Jabłonowski) poprzedzali bowiem obszernym wstępem, którego istotnym elementem były szacunki zaludnienia. Druga kontrowersja natomiast wynikła niejako z pierwszej i dotyczyła problemu wiarygodności i przydatności badawczej rejestrów podatkowych do badań historycznych. W niniejszym tekście spróbujemy przyjrzeć się pierwszej z nich i ocenić jej dotychczasowy plon.

\section{Szacunek liczby ludności wiejskiej}

Szacowanie liczby ludności wiejskiej Pawiński zaczął od gospodarstw kmiecych. Założył dla nich, że na każdy łan kmiecy przypadały średnio dwa gospodarstwa kmiece (półłanowe), a dla gospodarstwa kmiecego założył 5-6 osób jako łączną liczbę członków rodziny i służby. W efekcie otrzymał średni mnożnik 11 osób na łan kmiecy. Liczbę średnio dwóch gospodarstw na łan uzyskał zestawiając ze sobą dane dla województwa sieradzkiego pochodzące $\mathrm{z}$ rejestrów z 1552 roku (gdy opodatkowane były nie łany, ale kmiecie płacący od osoby po 2 grosze) i 1553 roku (gdy opodatkowane były łany stawką 12 groszy) ${ }^{4}$. Liczbę osób w gospodarstwie kmiecym ustalił natomiast w oparciu o dane dla kilku wsi powiatu pilzneńskiego (województwo sandomierskie) pochodzące ze szczątkowo zachowanego rejestru pogłównego z $1590 \mathrm{roku}^{5}$. Z zawartych w nim informacji wynikało, że w gospodarstwie uznanym przez niego za pełnołanowe było zwykle około 10-12 osób (6-8 członków rodziny oraz 2-4 osoby służby), a w gospodarstwie uznanym za półłanowe - 5-6 osób. W oparciu o tenże szczątkowy rejestr pogłównego średnią liczbę osób w rodzinie ogrodniczej wyliczył na 5, a komorniczej na 3-4 osoby i założył dla nich wspólny mnożnik 4 osób. Dla całej reszty ludności wiejskiej, do której zaliczył: młynarzy, karczmarzy, gorzelników, rzemieślników i przekupniów wiejskich, rybaków, hamerników i innych

\footnotetext{
${ }^{3}$ www.atlasfontium.pl (3.11.2015).

${ }^{4}$ Adolf Pawiński, Wielkopolska, [w:] Źródła Dziejowe, t. XII. Polska XVI wieku pod względem geograficzno-statystycznym, opr. Adolf Pawiński, t. 1: Wielkopolska, Warszawa 1883, s. 85-87.

${ }^{5}$ Tamże, s. 89-91.
} 
wymienianych w spisach, założył przelicznik 5 osób na gospodarstwo domowe. Nie wyartykułował tego w żaden sposób wprost w tekście, ale ewidentnie przyjął dla nich liczbę członków rodziny na poziomie identycznym, jak w rodzinach zagrodniczych. Przy czym liczbę młynów ustalił dzieląc liczbę kół młyńskich wykazanych w rejestrach przez 3, zakładając, że tyle kół średnio przypadało na młyn ${ }^{6}$.

W odniesieniu do szlachty i personelu dworskiego założył, że statystycznie na każdą wieś - niezależnie od typu własności, a więc dla własności szlacheckiej, królewskiej i kościelnej - przypadał jeden przeciętny dwór. Na jeden dwór natomiast założył średnio 11 osób (5 osób rodziny dworskiej i 6 osób czeladzi). W odniesieniu do szlachty nieposiadającej kmieci, przyjął obecność na każdym opodatkowanym łanie 2 rodzin szlacheckich liczących po 5 osób, do czego doliczył średnio 1 osobę czeladzi na łan i uzyskał w ten sposób mnożnik 11 osób na łan?.

Dla duchownych założył, że w każdej parafii obecny był jeden ksiądz oraz organista lub dzwonnik z rodziną. Dla rodzin organistów i dzwonników zastosował przelicznik 5 osób $^{8}$.

Tak skonfigurowane przeliczniki stosował bez poważniejszych zmian w kolejnych tomach obejmujących Małopolskę i Mazowsze, wprowadzając jedynie dwie poprawki. Począwszy od tomu XIV cyklu, zamiast wyliczać oddzielnie liczbę księży, a oddzielnie organistów lub dzwonników, zaczął stosować stały przelicznik dla parafii zakładający obecność 6 osób, co jednak w żaden sposób nie mogło wpłynąć na wcześniejsze szacunki, gdyż w efekcie liczba osób przypadających na parafię pozostała niezmieniona. Jedyna istotniejsza zmiana polegała na obniżeniu przelicznika dla rodziny rzemieślników wiejskich z 5 do 4 osób, przy czym nie wyjaśnił powodów tej zmiany, a jej wpływ na końcowe wyliczenia $-z$ uwagi na dość skromną reprezentację tej kategorii ludności - można uznać w skali całego kraju za nieistotny ${ }^{9}$. Poważniejszą zmianę wprowadził dopiero Aleksander Jabłonowski, który w tomie XVIII Źródeł Dziejowych w miejsce dotychczasowego założenia, że liczba dworów jest równa liczbie wsi, przyjął założenie, że jeden folwark szlachecki przypada na 46 opodatkowanych łanów kmiecych ${ }^{10}$.

${ }^{6}$ Tamże, s. 102-103.

${ }^{7}$ Tamże, s. $105-107$.

${ }^{8}$ Tamże, s. 107.

${ }^{9}$ Adolf Pawiński, Małopolska, [w:] Źródta Dziejowe, t. XIV. Polska XVI wieku pod względem geograficzno-statystycznym, opr. Adolf Pawiński, t. 3: Małopolska, Warszawa 1886, s. 39, tab. 12.

${ }^{10}$ Aleksander Jabłonowski, Ludność, [w:] Źródta Dziejowe, t. XVIII. Polska XVI wieku pod względem geograficzno-statystycznym, opr. Aleksander Jabłonowski, t. 7, cz. 2: Ziemie Ruskie, Ruś Czerwona, Warszawa 1903, s. 118-216. 


\section{Szacunek liczby ludności miejskiej}

Za podstawę do oszacowania liczby ludności miejskiej Pawiński zdecydował się przyjąć wpływy z szosu. Założył przy tym, że jedna złotówka podatku odpowiadała 24 osobom mieszkającym w mieście. Powołał się tutaj na dane zawarte w sumariuszu poborowym województwa łęczyckiego z roku 1569 (sporządzonym w 1571 roku). W oparciu o nie wyliczył łączną liczbę rzemieślników, rzeźników, karczmarzy, młynarzy i piwowarów (te zawody wymienił w tekście) na około 1400 osób, uznając tę liczbę za odpowiadającą liczbie rodzin rzemieślniczych i przyjął dla nich przelicznik 6 osób na gospodarstwo domowe. Do tego dodał liczbę 5850 osób ludności rolniczej zamieszkującej w miastach, którą wyliczył na podstawie liczby 450 łanów miejskich stosując przelicznik 13 osób na łan (11 osób przypadających na gospodarstwa kmiece i 2 osoby na hipotetyczne rodziny ogrodnicze). Następnie założył: liczbę duchownych w miastach na 350 osób; oficjalistów królewskich, grodowych i ziemskich na 500 osób; ludność żydowską na 500 osób. W efekcie tego wyliczenia otrzymał łączną liczbę 15700 osób ludności miejskiej województwa łęczyckiego w 1569 roku, którą podzielił przez 659 złotych szosu zebranego w tym województwie w 1578 roku, otrzymując 24 osoby na jedną złotówkę ${ }^{11}$. Przy czym stwierdził, że lepszym rozwiązaniem byłoby opieranie się w szacunku liczby ludności miast na kryterium liczby domów, sugerując jako możliwy do zastosowania w takiej sytuacji przelicznik 5-7 osób na dom. By ocenić prawidłowość zaproponowanego przelicznika 24 osób na złotówkę szosu, sięgnął do rejestru poborowego powiatu drohickiego z 1580, w którym szos - wobec włączenia go do Królestwa Polskiego dopiero w 1569 roku - wybierany był nie kwotowo z miasta, ale od pojedynczych domów wedle stawek ustalanych w uniwersałach poborowych: 8 gr od domów rynkowych, 4 gr od domów ulicznych i 2 gr od domów nędznych ${ }^{12}$. Zestawiając dla całego powiatu kwotę wpływów z liczbą domów wyliczył, że średnia stawka podatkowa na dom - dla którego zakładał przelicznik 6 osób - wynosiła 4 grosze, co w zestawieniu z założonymi stawkami szosu dawałoby tylko 3,5 osoby na dom. Uznał więc w tym miejscu, że przelicznik 24 osób na złotówkę szosu traktować należy jako minimalny poziom przy szacowaniu ludności miejskiej w małych miastach. Wyraził przy tym opinię, że dla miast o większej liczbie domów rynkowych możliwe jest, że na złotówkę szosu będą składać się 4 domy, co byłoby równoznaczne z 24 osobami na złotówkę szosu.

Przelicznik ten stosował konsekwentnie w kolejnych tomach, umieszczając w nich jedynie nowe analizy mające dowodzić jego poprawności. $\mathrm{W}$ tomie

\footnotetext{
${ }^{11}$ A. Pawiński, Wielkopolska [4], s. 111-112.

${ }^{12}$ Tamże, s. 114-115.
} 
poświęconym Małopolsce odwołał się do liczby domów określonych dla części miast w lustracjach dóbr królewskich i w taksacjach z lat 1536 i $1540^{13}$. Natomiast w tomie dotyczącym Mazowsza posłużył się powstałym w 1534 roku inwentarzem miasta Sierpca ${ }^{14}$.

\section{Krytyka przeliczników Pawińskiego}

Wypracowana przez Pawińskiego metoda szacowania liczby ludności dla schyłku XVI wieku w oparciu o rejestry podatkowe spotkała się z poważną krytyką Władysława Czerkawskiego. Uznał on szacunki Pawińskiego odnośnie do ludności wiejskiej za zaniżone i zaproponował podniesienie części przeliczników:

- liczby rodzin kmiecych przypadających na jeden opodatkowany łan z 2 na 2,5 (nie 11, lecz 14 osób na łan),

- liczby rodzin szlachty zagrodowej na jeden opodatkowany łan z 2 na 2,5, przy jednoczesnym zwiększeniu liczby zakładanej służby z 1 do 2 osób na rodzinę (17-18 osób na łan),

- liczby osób przypadających na jeden dwór z 11 do 15 ,

- liczby osób w rodzinach zagrodniczych i komorniczych z 4 na 5 ,

- dla rud, gorzelni, młynów itp. postulował zastosowanie przelicznika wyższego niż 5 osób, by uwzględnić personel pomocniczy i ewentualną służbę zajmującą się rolnictwem.

W odniesieniu natomiast do szacunku liczby ludności miejskiej odrzucił całkowicie możliwość wykorzystania w tym celu szosu. Wskazał na ryczałtowy w XVI wieku charakter tego podatku, a na przykładzie kilku miast, dla których wyliczenia dało się oprzeć na liczbie domów stwierdził, że przy założeniu 6 osób w rodzinie szacunki dawały zwykle znacznie wyższe liczby ludności niż wyliczenia oparte na szosie ${ }^{15}$. Sugestie dotyczące zwiększenia liczby gospodarstw kmiecych i rodzin szlachty zagrodowej na jeden opodatkowany łan poparł wynikami własnych badań sondażowych, przy czym wydaje się, że wykonał je na podstawie rejestrów opublikowanych przez Pawińskiego.

Opinię Czerkawskiego o konieczności odrzucenia rejestrów szosu jako podstawy do szacowania liczby ludności miejskiej podzielał też w swym opublikowanym w 1951 roku artykule Witold Kula ${ }^{16}$. Przede wszystkim stwierdził,

${ }^{13}$ A. Pawiński, Małopolska [9], s. 45-48.

${ }^{14}$ A. Pawiński, Mazowsze, [w:] Źródta Dziejowe, t. XVI. Polska XVI wieku pod względem geograficzno-statystycznym, opr. Adolf Pawiński, t. 5: Mazowsze, Warszawa 1895, s. 40.

${ }^{15}$ Włodzimierz Czerkawski, Metoda badania zaludnienia Polski w XVI wieku, ,Sprawozdania z Czynności i Posiedzeń Akademii Umiejętności” 2, 1897, s. 8-12.

${ }^{16}$ Witold Kula, Stan i potrzeby badań nad demografia historyczna dawnej Polski (do początków XIX wieku), „Roczniki Dziejów Społecznych i Gospodarczych” 13, 1951, s. 23-106. 
że mnożnik liczby osób stosowany przez Pawińskiego względem łanów miejskich jest zbyt niski, bo jego zdaniem uposażenie ziemią ludności miejskiej było zapewne dużo niższe niż ludności wiejskiej (a więc jego zdaniem gospodarstwa rolne na łanach uposażeniowych miast powinny być mniejsze). Po drugie zaś wyraził obawę, czy Pawiński uwzględnił w wyliczeniu istnienie plebsu miejskiego. Zakwestionował też jeden z dowodów Pawińskiego mający potwierdzać słuszność stosowania przelicznika 24 osób na złotówkę szosu, a mianowicie wyliczenia oparte na inwentarzu Sierpca. Pawiński ustalił bowiem w tym przypadku liczbę rzemieślników, ogrodników i właścicieli domów na 340 osób i stosując mnożnik 4 osób na dom (gospodarstwo domowe) ustalił liczbę mieszkańców na 1360 osób, podczas gdy z kwoty zapłaconego szosu uzyskał liczbę 1152 mieszkańców. Kula przedstawił trzy podstawowe zarzuty:

1. Przyjęcie w wyliczeniu zbyt niskiej liczby gospodarstw, bo inwentarz sporządzono w 1534 roku, a Pawiński liczył zaludnienie dla 1578 roku.

2. Zastosowanie zbyt niskiego przelicznika liczby osób na dom.

3. Nieuwzględnienie w wyliczeniu mieszkańców miasta nieposiadających domów, którzy nie pojawili się w inwentarzu, bo nie wiązały się z nimi żadne dochody.

Mimo tych obiekcji ostatecznie wykorzystał Kula szos w swym własnym szacunku zaludnienia Polski, przy czym powiększył liczbę osób przypadających na jedną złotówkę podatku o $50 \%$ i zastrzegł, że rozwiązanie to ma charakter „awaryjny”.

W odniesieniu do kalkulacji liczby ludności wiejskiej zarzucił przede wszystkim stosowanie przez Pawińskiego jednolitego w skali całego kraju przelicznika liczby gospodarstw kmiecych na łan. Powołał się przy tym na badania Jana Rutkowskiego $^{17}$, Edwarda Kozłowskiego ${ }^{18}$, Witolda Jakóbczyka ${ }^{19}$, Stefana Inglota ${ }^{20}$, Aleksandra Mościckiego ${ }^{21}$ i Stanisława Orsini-Rosenberga ${ }^{22}$ dla dóbr królewskich

\footnotetext{
${ }^{17}$ Jan Rutkowski, Statystyka zawodowa ludności wiejskiej w Polsce w drugiej połowie XVI w., Kraków 1918.

${ }^{18}$ Edward Kozłowski, Uwarstwienie ludności wiejskiej $w$ Wielkopolsce $w$ drugiej połowie XVI w., Poznań 1928.

${ }^{19}$ Witold Jakóbczyk, Uwarstwienie ludności wiejskiej w królewszczyznach zachodnich województw Korony w drugiej połowie XVI w., „Roczniki Dziejów Społecznych i Gospodarczych” 5, 1936, s. 45-68.

${ }^{20}$ Stefan Inglot, Stosunki społeczno-gospodarcze $w$ dobrach biskupstwa włocławskiego w pierwszej połowie XVI w., Archiwum Towarzystwa Naukowego we Lwowie, dział II, t. 3, nr 4, Lwów 1927.

${ }^{21}$ Aleksander Mościcki, Uwarstwienie ludności wiejskiej w dobrach kapituły gnieźnieńskiej w pierwszej połowie XVI w., „Roczniki Dziejów Społecznych i Gospodarczych” 2 (1932-1933), s. $113-122$.

${ }^{22}$ Stefan Orsini-Rosenberg, Rozwój i geneza folwarku pańszczyźnianego w dobrach katedry gnieźnieńskiej, Poznań 1925.
} 
i kościelnych w Wielkopolsce i części Małopolski. Na podstawie danych zawartych $\mathrm{w}$ pracach tych autorów wyliczył średnie nasycenie gospodarstwami kmiecymi dla tych dwóch typów dóbr na poziomie od 1,25 gospodarstwa na łan kmiecy w Wielkopolsce, poprzez 1,43 w województwie krakowskim, po 1,66 w województwie sandomierskim. Uwzględnienie nasycenia zagrodników, komorników i rzemieślników wiejskich w przeliczeniu na łan kmiecy (przejęte od Pawińskiego) dało mu wyraźną różnicę w nasyceniu ludnością rolniczą na poziomie od 2,12 rodziny na łan w Wielkopolsce, przez 2,43 w woj. krakowskim, po $2,83 \mathrm{w}$ sandomierskim ${ }^{23}$. Różnice te wiązał z odmiennym poziomem rozwoju folwarku, co jego zdaniem podważało przekonanie Pawińskiego o jednolitej w skali kraju proporcji areału kmiecego do folwarcznego. W miejsce jednolitego przelicznika zaproponował więc jego regionalne różnicowanie: dla Wielkopolski i województw mazowieckiego i rawskiego - 11 osób na łan kmiecy; dla krakowskiego i płockiego - 13 osób; dla sandomierskiego i lubelskiego - 15 osób ${ }^{24}$. Zaproponował także mechaniczne doszacowanie niedorejestrowanej jego zdaniem ludności niekmiecej. Dla Wielkopolski - na poziomie 50\% ludności kmiecej; mazowieckiego i rawskiego - 40\%; dla krakowskiego i płockiego - 60\%; dla sandomierskiego i lubelskiego - 70\%. Przelicznik liczby osób na folwark Pawińskiego uznał za właściwy dla folwarków najsłabiej zaludnionych, sugerując generalną konieczność jego podniesienia. Także dla szlachty zagrodowej stosowany współczynnik przeliczeniowy ocenił jako zaniżony, ale jego skorygowanie uznał za niemożliwe do wykonania bez badań w tym zakresie, przy czym obecność służby w gospodarstwach szlachty zagrodowej oceniał na 1/11 tej zbiorowości. Odrzucał przyjmowaną przez Pawińskiego jednolitą dla całego kraju proporcję między liczbą łanów kmiecych a folwarcznych jak 1:1, optując za jej zróżnicowaniem zależnie od regionu i typu własności.

Odmienne podejście prezentował Egon Vielrose. W opublikowanym w 1957 roku artykule Ludność Polski od X do XVIII wieku w części poświęconej szacunkowi zaludnienia w przekroju chronologicznym dla roku 1578 był generalnie dużo mniej krytyczny względem liczących wówczas już ponad pół wieku propozycji Pawińskiego. Weryfikując zarówno propozycje Pawińskiego, jak i krytyczne względem nich opinie Czerkawskiego, policzył - korzystając z rejestrów poborowych dla 1552 roku opublikowanych przez Pawińskiego, jak też $\mathrm{z}$ rejestrów niepublikowanych i lustracji - liczbę gospodarstw kmiecych przypadających na łan kmiecy w wybranych powiatach poszczególnych województw, uznając uzyskane wyniki za próbę pozwalającą na szacowanie wielkości tego wskaźnika dla większych obszarów (województw). Przy czym wyliczone

\footnotetext{
${ }^{23}$ W. Kula, Stan i potrzeby badań [16], s. 57.

${ }^{24}$ Tamże, s. 59-61.
} 
średnie przeliczył dla 1578 roku zakładając roczny wzrost liczby rodzin kmiecych o $0,4 \%$, uzyskując w ten sposób hipotetyczną liczbę gospodarstw dla 1578 roku i na podstawie danych o liczbie opodatkowanych w tym roku łanów wyliczył liczbę gospodarstw na jeden opodatkowany łan. Po tych przeliczeniach, zakładając zaludnienie gospodarstwa kmiecego na 6 osób, określił dla poszczególnych regionów wielkość przeliczników na łan kmiecy: dla Wielkopolski - 11 osób; dla województw krakowskiego i sandomierskiego - 13 i 15 osób; dla województwa lubelskiego - 17 osób; dla Mazowsza - 11 osób. Korzystając z rejestrów opublikowanych przez Pawińskiego, przeprowadził badania sondażowe (deklarował, że zwykle obejmował badaniem $50 \%$ danych zawartych w poszczególnych rejestrach) starając się oszacować średnią liczbę rodzin szlachty zagrodowej przypadającą na jeden opodatkowany łan dla wybranych powiatów. Stwierdził w efekcie, że postulat Czerkawskiego podniesienia liczby rodzin szlachty zagrodowej na łan do 2,5 jest zasadny tylko dla części województw.

Szacując liczbę ludności miejskiej oparł się, tak jak Pawiński, na szosie, negując przy tym możliwość wykorzystania do tego celu danych z rejestrów poboru miejskiego. Odrzucił jednak stosowanie jednolitego przelicznika 24 osób na jedną złotówkę szosu na rzecz zróżnicowanego zależnie od kwoty podatku opłacanego przez poszczególne miasta. Dla miast płacących do 20 złotych przyjął przelicznik 116 osób na jedną złotówkę; dla płacących 20-50 złotych - 71 osób; 50-100 złotych - 32 osoby; ponad 100 złotych - 18 osób. Propozycję tę oparł na szacunku zaludnienia 35 miast mazowieckich wykonanym przez Stanisława Pazyrę, który wykorzystał dane o liczbie domów i zastosował jednakowy dla wszystkich miast przelicznik 6 osób na dom ${ }^{25}$.

Publikacja Vielrosego wywołała błyskawiczną reakcję. Rok później ukazał się bowiem polemiczny względem jego tekstu artykuł Ireny Gieysztorowej i Tadeusza Ładogórskiego ${ }^{26}$. Autorzy kwestionowali w nim przede wszystkim - w odniesieniu do części poświęconej XVI wiekowi - wyliczenia Vielrosego dotyczące liczby gospodarstw kmiecych na jeden opodatkowany lan argumentując, że nie można zakładać istnienia „powiatów reprezentatywnych dla województwa". Zakwestionowali także dokładność jego obliczeń liczby rodzin szlachty zagrodowej oraz zasadność mechanicznego podnoszenia o $10 \%$ liczebności chłopskiej ludności niekmiecej. Całkowicie odrzucili też możliwość wykorzystania szosu do szacowania liczby ludności miejskiej w XVI wieku, argumentując to jego ryczałtowym charakterem w XVI wieku, jak też brakiem jakiegokolwiek związku między szosem a liczbą ludności w chwili jego pierwotnego naliczania

\footnotetext{
${ }^{25}$ Stanisław Pazyra, Studia z dziejów miast na Mazowszu od XIII do początków XX wieku, Lwów 1939, s. 281-283.

${ }^{26}$ Irena Gieysztorowa, Tadeusz Ładogórski, W sprawie nowych badań nad zaludnieniem dawnej Polski, „Kwartalnik Historii Kultury Materialnej” 6, 1958, nr 1-2, s. 45-60.
} 
w połowie XV wieku. Począwszy od tej chwili, to publikacje Ireny Gieysztorowej - a wśród nich przede wszystkim wydany w 1976 roku Wstęp do demografii staropolskiej ${ }^{27}$ oraz napisany kilka lat wcześniej w komentarzu do tomu Atlasu Historycznego Polski poświęconemu Mazowszu podrozdział Charakter $i$ wielkość $o s a d^{28}$ (a nie dzieło Adolfa Pawińskiego) - stały się wyznacznikiem standardów przyjmowanych przy szacowaniu ludności Polski w XVI wieku na bazie źródeł podatkowych. Przede wszystkim w ramach szacunków liczby ludności kmiecej stosowała ona zmienny przelicznik liczby osób na łan, zależnie od stwierdzonej średniej liczby gospodarstw kmiecych na jeden łan. W przypadku Mazowsza wynosił on 10 osób we wsiach należących do własności królewskiej, kościelnej oraz w kilkunastołanowych wsiach będących w rękach jednego właściciela szlacheckiego. We wsiach o rozproszonej własności, należących do szlachty określanej jako cząstkowa, stosowała przelicznik 11-13 osób na opodatkowany łan kmiecy. Zróżnicowanie to wynikało $\mathrm{z}$ zestawiania danych $\mathrm{z}$ rejestru poborowego 1552 roku z rejestrami z 1563 roku, wskazującego na większe rozmiary gospodarstw w majątkach większej własności. Dla szlachty zagrodowej stosowała przelicznik 11 osób na łan. Dla rodzin szlacheckich i rzemieślników wiejskich przyjęła dla Mazowsza przelicznik 5 osób, natomiast dla ogrodników i komorników 4 osoby. Czeladź folwarczna szacowana była na 5 osób na folwark, aczkolwiek badaczka nie podała informacji o zakładanym poziomie obecności folwarków. W przypadku szacunku zaludnienia miast - wobec niemiarodajności szosu, który odrzucała całkowicie i problemów dostrzeganych w wykorzystywaniu poboru miejskiego do badań demograficznych - opierała się na liczbie domów (tam gdzie tego rodzaju dane istniały), przyjmując dla Mazowsza przelicznik 6-7 osób na dom ${ }^{29}$. Zastrzegła jednak przy tym, że metoda ta jest negatywnie oceniana w badaniach zachodnioeuropejskich. Dane o liczbie rzemieślników wykazywanych w rejestrach poboru miejskiego, jak też fakt zlokalizowania centrów administracyjnych czy klasztorów w poszczególnych miastach, były przez nią wykorzystane jedynie w celu określenia przybliżonych rozmiarów ośrodków miejskich. Sposób operowania przelicznikami, a zwłaszcza technika prowadzenia szacunku ludności miast, były pochodną celu jego dokonywania oraz oczekiwaną precyzją, wynikającą z założeń stworzonych na potrzeby publikacji kolejnych tomów Atlasu

\footnotetext{
${ }^{27}$ Irena Gieysztorowa, Wstep do demografii staropolskiej, Warszawa 1976.

${ }^{28}$ Irena Gieysztorowa, Charakter i wielkość osad, [w:] Atlas Historyczny Polski. Mazowsze w połowie XVI wieku, red. Władysław Pałucki, część II: Komentarz, indeksy, Warszawa 1973, s. 77-87.

${ }^{29} \mathrm{~W}$ przypadku poboru miejskiego chodziło o brak pewności co do zasadności odrębnego kalkulowania zaludnienia dla ziemi uprawnej będącej uposażeniem miast. Wynikało to z niedającego się określić zakresu nakładania się zajęć rolniczych i pozarolniczych mieszczan, patrz: I. Gieysztorowa, Charakter i wielkość osad [28], s. 83.
} 
Historycznego Polski. Celem nie był tutaj szacunek liczby ludności regionu, lecz jedynie zakwalifikowanie poszczególnych osad wiejskich i ośrodków miejskich do wyodrębnianych kategorii wielkości sygnalizowanych na mapie odmiennymi znacznikami. W przypadku osad wiejskich były to dwie kategorie: do 200 osób i ponad 200 osób. Dla miast wyodrębniono trzy kategorie: do 1000 mieszkańców; 1000-5000 mieszkańców; ponad 5000 mieszkańców. Także we Wstępie do demografii Irena Gieysztorowa wyraziła opinię o konieczności stosowania elastycznego wskaźnika liczby osób na łan, określanego na podstawie danych zawartych $\mathrm{w}$ inwentarzach dla dóbr królewskich i kościelnych, a dla szlacheckich $-\mathrm{z}$ zestawiania danych z rejestrów poborowych ${ }^{30}$. W przypadku szacunków zaludnienia dla ziem, województw lub całego kraju optowała za wykorzystaniem danych o średniej wielkości gospodarstw kmiecych wynikających z porównania liczbie kmieci w rejestrze poborowym 1552 roku i liczby łanów zawartych w rejestrze z 1563 roku. Sugerowała wykorzystanie rejestrów podstawowych i wyliczanie średniej na poziomie powiatów. Uznawała jednocześnie zasadność stosowania jednolitego w skali kraju przelicznika liczby 6 osób dla rodziny kmiecej i dla rodzin zagrodniczych. Dla miast - podtrzymując opinię o problematycznej przydatności rejestrów poborowych do analiz demograficznych - sugerowała korzystanie tam, gdzie to możliwe, z liczby domów i używanie średniego mnożnika 6-7 osób na dom, przy czym w przypisie sugerowała stosowanie mnożnika 8 osób nie precyzując jednak, czy w skali całego kraju i czy we wszystkich miastach, czy też tylko w wybranych ${ }^{31}$.

W zasadzie zgodnie z określonymi przez Irenę Gieysztorową w tych dwóch publikacjach zasadami została przeprowadzona przez Annę Dunin-Wąsowicz w kolejnym tomie Atlasu Historycznego analiza wielkości osad województwa sandomierskiego. Dla dóbr królewskich i kościelnych - charakteryzujących się większą średnią wielkością gospodarstwa - przyjęty został mnożnik 10 osób na łan, a dla szlacheckich - o wyraźnie mniejszych gospodarstwach - 12,5 osób na łan. Wszystkie pozostałe przeliczniki liczebności rodzin przejęte zostały natomiast $\mathrm{z}$ tomu poświęconemu Mazowszu: zagrodnicy i komornicy - 4 osoby na rodzinę, rzemieślnicy - 5 osób, szlachta -5 osób, szlachta zagrodowa -11 osób na łan ${ }^{32}$. Przy szacowaniu zaludnienia ośrodków miejskich - kwalifikując poszczególne miasta do określonego rzędu wielkości - brano pod uwagę dane zawarte $w$ rejestrach poborowych oraz szereg innych czynników, podobnie jak w tomie mazowieckim. Tam, gdzie to możliwe, weryfikowano to wykorzystując

\footnotetext{
${ }^{30}$ I. Gieysztorowa, Wstęp [27], s. 163, 180-182.

${ }^{31}$ Tamże, s. 184.

${ }^{32}$ Anna Dunin-Wąsowicz, Charakter i wielkość osiedli, [w:] Atlas Historyczny Polski, t. 2: Województwo sandomierskie w drugiej połowie XVI wieku, red. Władysław Pałucki, część II: Komentarz, indeksy, Warszawa 1993, s. 83-85.
} 
podymne lub pogłówne z XVII wieku, przy czym przelicznik liczby osób na dom dla tego województwa ustalony został w oparciu o próbę wykonaną dla powiatu radomskiego, dla którego miast zestawiono ze sobą dane z pogłównego 1662 roku i podymnego z 1667. Uzyskane wskaźniki dla poszczególnych ośrodków wyniosły od 5 do 16 osób na dom, a średnia dla powiatu -9 osób ${ }^{33}$. Tak uzyskany przelicznik był stosowany dla całego województwa.

W kolejnym tomie Atlasu, poświęconym województwom łęczyckiemu i sieradzkiemu, przyjęte zostały przeliczniki jak w dwóch poprzednich tomach. Dla terenów wiejskich stosowano przelicznik 10-13 osób na łan kmiecy zależnie od wielkości osiedla, liczby działów i rodzaju własności, a przeliczniki dla zagrodników, komorników, rzemieślników, szlachty, szlachty zagrodowej przejęto takie, jak w tomach dla Mazowsza i województwa sandomierskiego. Do kwalifikacji miast do poszczególnych kategorii wielkości ponownie wykorzystano, jak w poprzednich tomach, rejestry poborowe wraz z informacjami o obecności centrów administracyjnych i instytucji kościelnych. Ocenę wielkości miasta weryfikowano - w miarę możliwości - wykorzystując podymne z XVII wieku, przy czym stosowano jako przelicznik liczby osób na dom średnią wartość wyliczoną dla województwa sandomierskiego -9 osób $^{34}$. Ten sam przelicznik zastosowano w trakcie analizowania wielkości miast w tomie dotyczącym województwa krakowskiego, modyfikując jednocześnie przeliczniki stosowane dla terenów wiejskich ${ }^{35}$. Dla ludności kmiecej zastosowany został jednolity przelicznik 14 osób na łan kmiecy, dla gospodarstw młynarskich i karczmarskich -6 osób, dla ogrodniczych 5 osób, dla komorniczych -4 osoby, dla rzemieślniczych -5 osób.

Rozpatrując historię dyskusji nad przelicznikami demograficznymi zastosowanymi przez Adolfa Pawińskiego w 1883 roku oddzielnie dla ludności wiejskiej i miejskiej widoczne jest, że mimo silnej krytyki jego przeliczniki dla ludności wiejskiej okazały się wyjątkowo trwałe. Przez ponad sto lat jedynym elementem konstrukcji, który ulegał zmianom, był przelicznik liczby gospodarstw kmiecych na jeden opodatkowany łan i wynikające z tego zmiany w kalkulacji liczby osób przypadających na jeden łan kmiecy. Wynikało to z kwestionowania zasadności stosowania jednolitego w skali kraju przelicznika 2 gospodarstw na jeden opodatkowany łan na rzecz jego lokalnego zróżnicowania. Natomiast proponowane przez Pawińskiego przeliczniki liczebności rodzin ogrodników, komorników,

\footnotetext{
${ }^{33}$ Tamże, s. 81.

${ }^{34}$ Krzysztof Chłapowski, Charakter i wielkość osiedli, [w:] Atlas Historyczny Polski, t. 5: Województwo sieradzkie $i$ województwo tęczyckie $i$ w drugiej połowie XVI wieku, red. Henryk Rutkowski, część II: Komentarz, indeksy, Warszawa 1998, s. 50-55.

${ }^{35}$ Jarosław Suproniuk, Charakter i wielkość osiedli, [w:] Atlas Historyczny Polski, t. 1: Województwo krakowskie w drugiej połowie XVI wieku, red. Henryk Rutkowski, część II: Komentarz, indeksy, Warszawa 2008, s. 69-82.
} 
młynarzy, karczmarzy, rzemieślników, kmieci i szlachty (w tym szlachty zagrodowej) pozostawały w zasadzie niezmienne. Sugestia Ireny Gieysztorowej by dla rodzin kmiecych i zagrodniczych stosować mnożnik 6 osób na gospodarstwo pozostawała przez długi czas bez echa. Tymczasem badania dla Małopolski sugerują liczebność gospodarstw tych dwóch kategorii ludności wiejskiej w tym regionie na poziomie 7-8 osób. Ta zwiększona względem założeń Pawińskiego liczebność rodzin była efektem przede wszystkim doszacowywania w badaniach liczby dzieci, czego Pawiński nie robił ${ }^{36}$. W przypadku analizowanych powyżej tomów Atlasu Historycznego dopiero w tomie poświęconym województwu krakowskiemu z 2008 roku widać zmiany w tym zakresie, polegające na podniesieniu przelicznika dla gospodarstw młynarzy i karczmarzy do 6 osób oraz oddzielenia zagrodników od komorników z zastosowaniem dla tych pierwszych wyższego przelicznika na poziomie 5 osób. W przypadku ludności miejskiej, o ile kluczowy dla kalkulacji Pawińskiego pomysł wykorzystania szosu do szacowania ludności przy przeliczeniu 24 osób na złotówkę został - za wyjątkiem próby jego modyfikacji podjętej prze Vielrosego - odrzucony w zupełności, to w użyciu przez długi czas pozostawał zaproponowany przez Pawińskiego przelicznik 6 osób na dom.

Podstawowym zarzutem względem zaproponowanego przez Pawińskiego wykorzystania szosu do kalkulacji liczby ludności miast był ryczałtowy charakter tego podatku w XVI wieku i brak związku między podstawą jego naliczania w połowie XV wieku (wartość majątku) a liczbą mieszkańców miasta. Tymczasem już sam sposób, w jaki Pawiński doszedł do przelicznika 24 osób na złotówkę podatku - pomijając wątpliwą przydatność szosu do badań demograficznych - nakazywałby z olbrzymią rezerwą podchodzić do wszelkich wyliczeń tegoż autora. Wydaje się bowiem, że wielkość tego przelicznika narodziła się jeszcze zanim przeprowadził on jakiekolwiek analizy źródłowe mające wykazywać słuszność jego stosowania. Jednocześnie dobór źródeł i sposób pracy z nimi sugerują dość swobodny stosunek do nich Pawińskiego, przejawiający się choćby brakiem refleksji nad wpływem treści uchwał poborowych (zmieniających zasady opodatkowania i jego podstawę) na zawartość powstających w ich efekcie źródeł. Do takich wniosków dojść można śledząc przytaczane przez niego w kolejnych tomach Polski XVI wieku... dowody mające uzasadnić słuszność stosowania przelicznika 24 osób na złotówkę szosu. Już pierwsza jego kalkulacja, oparta o dane o liczbie rzemieślników i łanów miejskich opodatkowanych w ramach poboru miejskiego w województwie łęczyckim w 1569 roku i będąca teoretycznie podstawą

\footnotetext{
${ }^{36}$ Przegląd badań w tym zakresie wraz z ich wynikami prezentuje Cezary Kuklo, Wielkość i struktura gospodarstwa domowego w Polsce wczesnonowożytnej. Próba charakterystyki, [w:] Cała historia to dzieje ludzi... Studia z historii społecznej ofiarowane profesorowi Andrzejowi Wyczańskiemu w 80-ta rocznicę urodzin i 55-lecie pracy naukowej, red. Cezary Kuklo przy współudziale Piotra Guzowskiego, Białystok 2004, s. 167-181.
} 
do stosowania zaproponowanego przelicznika, zawiera w sobie kilka istotnych błędów. Pomijając fakt zryczałtowania szosu, do udziału w jego opłacaniu zobowiązani byli wyłącznie mieszczanie mający pełnię praw miejskich, a więc posiadający nieruchomości w obrębie miasta. Tymczasem do udziału w opłacaniu poboru miejskiego w 1569 roku - wykorzystanego przez Pawińskiego jako podstawa jego kalkulacji - zobowiązani byli wyłącznie ci mieszkańcy miast, którzy nie brali udziału w opłacaniu szosu. Jedynie w roku 1563, gdy po raz pierwszy uchwalono pobór miejski, obowiązkiem jego opłacania objęto wszystkich rzemieślników miejskich. W kolejnych latach aż do roku 1578 obowiązek ten ciążył jedynie na osobach niebiorących udziału w opłacaniu szosu. Także doliczeni przez niego oficjaliści (500 osób), Żydzi (500 osób) i duchowni (350 osób) nie brali udziału w opłacaniu szosu. Zasadniczo więc jego kalkulacja była błędna już na poziomie doboru danych. Jedynie na skutek zamieszania, jakie panowało w trakcie opłacania poboru miejskiego w województwie łęczyckim w latach sześćdziesiątych, w stworzonej przez niego zbiorowości statystycznej znalazła się część osób rzeczywiście opłacających szos. W części miast tego województwa nie tylko bowiem w 1563 roku, ale także w 1564 i 1565 pobór miejski opłacili wszyscy mieszczanie bez wyjątku. Jednak nie w 1569 roku. Ujawnia to zestawienie ze sobą liczby opodatkowanych w miastach województwa rzemieślników w wybranych latach na przestrzeni od 1564 do 1582 roku $^{37}$ :

1564 - 1192 rzemieślników,

1565 - 1467 rzemieślników,

1569 - 866 rzemieślników,

1580 - 1394 rzemieślników,

1581 - 1270 rzemieślników,

1582 - 1251 rzemieślników.

W rzeczywistości więc liczba łączna rzemieślników opłacających szos, jak i nie robiących tego wynosiła około 1400-1500 osób, a nie 866 uwzględnionych przez Pawińskiego w wyliczeniu. Gdybyśmy uwzględnili w tym zestawieniu, tak jak to robił Pawiński, także karczmy, młyny i gorzelnie, uznając je za odpowiadające każdorazowo jednej rodzinie rzemieślniczej zajmującej się ich prowadzeniem, wówczas dla lat sześćdziesiątych liczba opodatkowanych miejskich jednostek gospodarczych wynosiłaby:

1564 - 1703 jednostki,

1565 - 1938 jednostek,

1569 - 1432 jednostki.

${ }^{37}$ Archiwum Główne Akt Dawnych w Warszawie (dalej: AGAD), Archiwum Skarbu Koronnego (dalej: ASK), o. I, ks. 16, k. 266-280v; ks. 16, k. 442-472v; ks. 15, k. 407-428; ks. 15, k. $630-645 \mathrm{v}$; ks. 15 , k. $762-774$. 
Dla lat 1580-1582 wykonanie takiego obliczenia nie jest możliwe, gdyż od 1578 roku wprowadzono nowe zasady opłacania czopowego i zaprzestano ryczałtowego opodatkowywania karczem, które przestały się niniejszym pojawiać w rejestrach poborowych.

Wątpliwości budzą także inne elementy składowe jego szacunku. Zakładając liczbę duchowieństwa na 350 osób i oficjalistów na 500 osób, Pawiński w ogóle nie wskazał, w jaki sposób je wyliczył. Szacując liczbę ludności żydowskiej na 500 osób przywołał dane z rejestru poboru miejskiego z 1576 roku, w którym dla Łęczycy zawarto informację o obecności skupiska ludności żydowskiej liczącego 114 osób i opłacającego podatek w wysokości 50 florenów. Ponieważ stawka pogłównego żydowskiego w owym okresie została ustalona na 1 złoty i opłacać mieli ją wszyscy Żydzi bez względu na wiek i płeć, założył on, że wobec tego w skali całego województwa - w związku z założoną przez niego obecnością skupisk żydowskich we wszystkich miastach - ich liczbę można oceniać na 500 osób $^{38}$. Tymczasem rejestr poborowy, na który się powoływał - z 1576 roku wymienia tylko dwa ośrodki miejskie jako miejsca obecności ludności żydowskiej: Łęczycę, w której ściągnięto podatek, i Krośniewice, w których podatku nie zebrano w związku ze zwolnieniem z powodu pożaru miasta ${ }^{39}$. Ponieważ rejestr z 1576 roku jest chyba najmniej wiarygodnym spośród wszystkich rejestrów powstałych w drugiej połowie XVI wieku, optymistyczne założenie Pawińskiego można by było więc uznać za uzasadnione, gdyby nie to, że dane zawarte w rejestrach pochodzących z lat 1564, 1566 i po 1578 roku, wskazują, że szacunek Pawińskiego jest mocno zawyżony. W roku 1564 Żydzi wykazani są w trzech miastach: Łęczycy, Krośniewicach i Brzezinach. W Łęczycy zgodnie z deklaracją starszyzny żydowskiej zamieszkiwało 179 osób, przy czym podatek opłaciła tylko część z nich w łącznej kwocie 130 florenów; w Krośniewicach rejestr wykazuje obecność 12 Żydów i uiszczony podatek w wysokości 12 florenów; w Brzezinach natomiast zarejestrowana została wpłata podatkowa w wysokości 2 florenów ${ }^{40}$. W 1566 roku ponownie mamy do czynienia z zarejestrowaną obecnością Żydów w trzech ośrodkach miejskich: Łęczycy, Krośniewicach i Grabowie. W Łęczycy było 171 osób, a podatek wyniósł 114 florenów, natomiast Żydzi mieszkający $\mathrm{w}$ dwóch pozostałych miastach nie uiścili podatku ${ }^{41}$. W pochodzącym natomiast $\mathrm{z}$ okresu między rokiem 1578 a końcem lat osiemdziesiątych niedatowanym sumariuszu poborowym województwa łęczyckiego wykazano z kolei obecność Żydów jedynie w dwóch miastach: w Łęczycy miały to być 194 osoby,

${ }^{38}$ Volumina Constitutionum, t. 2 1550-1609, vol. 1 1550-1585, opr. Stanisław Grodziski, Irena Dwornicka, Wacław Uruszczak, Warszawa 2005, s. 259, 376.

${ }^{39}$ AGAD, ASK, o. I, ks. 15, k. 158-159.

${ }^{40}$ AGAD, ASK, o. I, ks. 16, k. 281-281v.

${ }^{41}$ AGAD, ASK, o. I, ks. 16, k. 465v. 
przy czym podatek został opłacony w kwocie 70 florenów, a w Krośniewicach wpłata podatkowa wyniosła 3 floreny ${ }^{42}$. Tak więc w skali województwa obecność ludności żydowskiej w miastach wypadałoby oceniać raczej na około 200 osób, a nie 500. Pawiński nie uwzględnił także - o co zresztą podejrzewał go już Witold Kula - wykazanych w sumariuszu z 1569 roku komorników (361 osób) i ludzi luźnych (92 osoby $)^{43}$. Na dodatek do wyliczenia liczby osób przypadających na jedną złotówkę szosu użył danych o wysokości wpływów z tego podatku z roku 1578 a nie z 1569, z którego pochodziły dane o liczbie rzemieślników. Jeśli zamiast 659 złotych zebranych w 1578 roku (suma zapewne została przez niego wzięta z sumariusza dla 1578 roku) wykorzystać do przeliczenia kwotę wpływów z szosu wynikającą z zsumowania wpłat poszczególnych miast wykazanych w sumariuszu 1569 roku, to uzyskane 757 złotych i 8 groszy przekładałoby się na maksymalny przelicznik 21 osób na złotówkę szosu ${ }^{44}$.

Podejmowane przez Pawińskiego na podstawie innych danych źródłowych analizy mające uzasadnić poprawność stosowania przelicznika 24 osób na złotówkę szosu opierały się na swobodnym operowaniu przelicznikiem liczby osób na dom w miastach. Jeszcze w XII tomie Źródet Dziejowych stwierdził - bez wskazywania jakichkolwiek danych źródłowych - że w przypadku domów miejskich należałoby stosować mnożnik 5-7 osób na dom. Jednocześnie jednak w tym samym tomie dla powiatu drohickiego w oparciu o dane z szosu dla 1580 roku średnie zaludnienie domu w miastach wyliczył na poziomie 3,5 osoby. Stwierdził więc, że dla małych miast zjawiskiem typowym byłaby obecność około 4 osób na dom (przekładająca się na około 7 domów na złotówkę szosu), natomiast dla miast dużych - około 6 osób na dom (4 domy na złotówkę szosu). Nie zwrócił jednak przy tym uwagi na to, że wyliczona liczba domów na złotówkę szosu w powiecie drohickim była wynikiem stosowanych tam stawek podatkowych w wysokości 8 groszy od domów rynkowych, 4 groszy od ulicznych i 2 groszy od pozostałych, dając $w$ efekcie średnią nieco ponad 4 grosze na opodatkowany dom. Tymczasem na ziemiach starej Korony szos pierwotnie naliczany był od wartości majątku, a nie liczby domów. W tomie XIV Źródeł Dziejowych, obejmującym Małopolskę, zastosował do wyliczeń nowy, wyższy przelicznik liczby osób na dom - 8 osób bez względu na wielkość miasta, przy czym uzyskał go korzystając $z$ danych o liczbie domów dla pięciu miast województwa krakowskiego wziętej z lustracji królewszczyzn oraz z kwoty szosu uiszczonej przez te ośrodki w 1569 roku. W oparciu o szos wyliczył liczbę mieszkańców na 6120 osób i podzieliwszy przez liczbę domów, uzyskał 8 osób na dom. Tak wyliczoną średnią

\footnotetext{
${ }^{42}$ AGAD, ASK, o. I, ks. 16, k. 683.

${ }^{43}$ AGAD, ASK, o. I, ks. 112, k. 66v-67.

${ }^{44}$ AGAD, ASK, o. I, ks 112, k. 66v.
} 
wykorzystał następnie do weryfikowania szacunku zaludnienia wybranych miast województwa sandomierskiego, gdzie otrzymał dane zbieżne zarówno przy obliczaniu w oparciu o szos, jak i liczbę domów ${ }^{45}$. Kilka elementów w tej konstrukcji budzi jednak uzasadnione wątpliwości. Po pierwsze, gdyby pięć miast z zestawienia Pawińskiego potraktować oddzielnie, wówczas jedynie w odniesieniu do jednego z nich - Jasła - można stwierdzić istnienie jakiejś zbieżności między wyliczeniem liczby ludności w oparciu o liczbę domów z wykorzystaniem przelicznika 8 osób a szosem z wykorzystaniem przelicznika 24 osób.

Tabela 1. Kalkulacja liczby mieszkańców Jasła, Częstochowy, Żarnowca, Słomnik

i Koszyczek dla drugiej połowy XVI wieku w oparciu o liczbę domów i kwotę uiszczonego szosu

\begin{tabular}{lcccc}
\hline \multicolumn{1}{c}{ Miasto } & Liczba domów & $\begin{array}{c}\text { Liczba } \\
\text { mieszkańców } \\
(8 \text { osób na dom })\end{array}$ & Kwota szosu & $\begin{array}{c}\text { Liczba mieszkańców } \\
(24 \text { osoby } \\
\text { na złotówkę })\end{array}$ \\
\hline Jasło & 135 & 1080 & $50 \mathrm{fl} .12 \mathrm{gr}$. & 1210 \\
Częstochowa & 218 & 1744 & $43 \mathrm{fl} .6 \mathrm{gr}$ & 1037 \\
Żarnowiec & 196 & 1568 & $44 \mathrm{fl} .24 \mathrm{gr}$ & 1076 \\
Słomniki & 104 & 832 & $59 \mathrm{fl} .21 \mathrm{gr}$. & 1433 \\
Koszyczki & 83 & 664 & $57 \mathrm{fl} .18 \mathrm{gr}$. & 1383 \\
\hline
\end{tabular}

Źródło: obliczenia własne na podstawie A. Pawiński, Małopolska [9], s. 46-48.

Po drugie, całe wyliczenie Pawińskiego rozpada się, jeśli dodamy do tego zestawienia jeszcze jeden ośrodek miejski przez niego pominięty, dla którego jednak możemy w oparciu o lustrację odtworzyć liczbę opłacających czynsz domów - Proszowice ${ }^{46}$. Jeśli uwzględnimy w zestawieniu 147 domów z tego miasta oraz 160 florenów opłacanego przez jego mieszkańców szosu, otrzymamy w efekcie 883 domy i 415 florenów szosu. Szacunek liczby osób w oparciu o szos dałby 9960, co przekładałoby się na ponad 11 osób na dom. Po trzecie wreszcie, niepokój budzi olbrzymia różnica zachodząca w przypadku danych podawanych przez $\mathrm{Pa}-$ wińskiego dla miast województwa sandomierskiego w zakresie liczby domów dla 11 miast królewskich z lustracji 1564 roku i 11 miast prywatnych z taksacji dóbr z lat 1536 i 1540. Dla miast królewskich Pawiński powołał się na lustrację z roku 1564 jako źródło danych i ogólną liczbę domów wyliczył na 2276, które przemnożył przez 8 osób, otrzymując około 18200 osób (dokładnie 18208). Z szosu

${ }^{45}$ A. Pawiński, Małopolska [9], s. 46-48.

${ }^{46}$ Lustracja województwa krakowskiego 1564, cz. I, wyd. Jan Małecki, Warszawa 1962, s. 43. Lustracja rejestruje czynsz ze 110 domów należących do mieszczan niewarzących ani nieszynkujących piwa i z 37 domów warzących bądź szynkujących piwo. 
wyszło mu natomiast około 20000 osób ( 854 złote $\times 24$ osoby $=20496$ osób). Dla 11 miast prywatnych ustalił liczbę domów na 991 i w oparciu o nią obliczył ludność na 7928 osób, a z kalkulacji opartej na szosie (342 złote) liczbę ludności wyliczył na 8208 osób. Tymczasem liczba domów w miastach królewskich wykazywanych w wersji lustracji zarówno użytej przez Pawińskiego, jak i będącej w 1963 roku podstawą wydawniczą wersji opublikowanej drukiem przez Ochmańskiego, miejscami mocno różni się od danych prezentowanych w tomie XIV Źródet Dziejowych ${ }^{47}$.

Tabela 2. Zestawienie informacji o liczbie domów w miastach królewskich województwa sandomierskiego

\begin{tabular}{lccc}
\hline \multicolumn{1}{c}{ Miasto } & $\begin{array}{c}\text { Liczba domów } \\
\text { według Pawińskiego }\end{array}$ & $\begin{array}{c}\text { Liczba domów } \\
\text { wykazanych w wydanej } \\
\text { drukiem lustracji }\end{array}$ & $\begin{array}{c}\text { Liczba domów } \\
\text { w wersji lustracji, } \\
\text { z której korzystał } \\
\text { Pawiński }\end{array}$ \\
\hline Radom & 180 & 121 & 125 \\
Zwoleń & 258 & 221 & 247 \\
Kozienice & 171 & 177 & 156 \\
Stężyca & 239 & 137 & 217 \\
Chęciny & 296 & 283 & 296 \\
Szydłów & 181 & 125 & 128 \\
Połaniec & 284 & 287 & 284 \\
Zawichost & 144 & 126 & 144 \\
Wiślica & 163 & 147 & 163 \\
Nowe Miasto Korczyn & 180 & 148 & 174 \\
Pilzno & 180 & 166 & 180 \\
Pierzchnica & $\mathbf{2 2 7 6}$ & 40 & 42 \\
Razem & $\mathbf{2 2 0 7 8}$ & $\mathbf{2 1 5 6}$ \\
\hline
\end{tabular}

Źródło: A. Pawiński, Małopolska [9], s. 46-48; Lustracja województwa sandomierskiego 1564-1565, wyd. Władysław Ochmański, Wrocław-Warszawa-Kraków 1963, s. 21, 25, 66, 92, 143, 153, 158, 162, 204, 218, 246, 282; AGAD, MK, XVIII, sygn. 28, k. 10v-12v, 57-66v, 112-119v, 168v-174; AGAD, MK, XVIII, sygn. 29, k. 35v, 90, 128, 181v, 230v, 248, 280.

W wykazie miast sporządzonym przez Pawińskiego - dla których lustracja operuje liczbą domów - Pawiński nie uwzględnił Pierzchnicy. Pozostawiając na boku przyczyny pojawienia się różnic między źródłem a zestawieniem Pawińskiego, należy tu wskazać, że dla niektórych ośrodków dane są zawyżone.

${ }^{47}$ Lustracja województwa sandomierskiego 1564-1565, wyd. Władysław Ochmański, Wrocław-Warszawa-Kraków 1963, s. 21, 25, 66, 92, 143, 153, 158, 162, 204, 218, 246, 282; AGAD, Metryka Koronna (dalej: MK), XVIII, sygn. 28, k. 10v-12v, 57-66v, 112-119v, 168v-174; AGAD, MK, XVIII, sygn. 29, k. 35v, 90, 128, 181v, 230v, 248, 280. 
W Stężycy różnica między dwiema wersjami lustracji wynika z zsumowania należności czynszowych do pełnych działek, podczas gdy wersja wykorzystana przez Pawińskiego zawiera wykaz imienny mieszczan, którzy w znakomitej większości posiadają jedynie połówki standardowych działek miejskich. W Połańcu i Chęcinach podana liczba domów obejmuje nie tylko domy miejskie, ale także z przedmieścia, a w Wiślicy liczba 163 jednostek dotyczy łącznie placów $\mathrm{z}$ domami, jak i działek niezabudowanych.

Gdyby przyjąć liczbę domów wykazanych w wersji lustracji wykorzystanej przez Pawińskiego jako podstawę szacunku zaludnienia stosując przelicznik 8 osób na dom, otrzymamy 17248 osób. Natomiast jeśli oprzeć się na szosie, a więc wykorzystanej przez Pawińskiego kwocie 854 złotych powiększonej o 9 złotych 18 groszy opłacanych przez Pierzchnicę, otrzymamy wówczas 20724 osoby. Ponieważ wykorzystany przelicznik 8 osób został wyliczony na podstawie danych z szosu, trudno powyższe wyliczenie uznać za potwierdzające słuszność kalkulacji opartych bezpośrednio na szosie.

Ostatnim wywodem mającym uzasadniać stosowanie przelicznika 24 osób na złotówkę szosu była wykonana w tomie XVI Źródet Dziejowych, poświęconym Mazowszu, analiza inwentarza dochodów czynszowych miasta Sierpca, który został sporządzony w 1534 roku w trakcie podziału majątkowego miasta między dwie córki Prokopa Sierpskiego. W oparciu o tenże inwentarz Pawiński stwierdził zamieszkiwanie w Sierpcu w tymże roku 340 rodzin, przy czym zakładał, że oddzielne rodziny stanowili „każdy rzemieślnik, ogrodnik i właściciel domu". Po zastosowaniu przelicznika 4 osób na rodzinę otrzymał liczbę 1360 mieszkańców miasta. Tak niski przelicznik zastosował, „żeby nie używać wobec takiego przypuszczenia zbyt wielkiego czynnika". Natomiast w oparciu o wysokość opłacanego szosu, stosując przelicznik 24 osób na jedną złotówkę, liczbę ludności oszacował na 1152 osoby $^{48}$. Ponieważ jednocześnie opublikował tenże inwentarz, możemy zweryfikować jego wyliczenia. Przede wszystkim trudno jest dojść, w jaki sposób Pawiński doszedł do liczby 340 rodzin w mieście. W inwentarzu mamy bowiem uwzględnione opłaty czynszowe z 273 działek miejskich z domami, 23 działek niezabudowanych, 47 ogrodów, 4 działów ziemi uprawnej określanej jako predium oraz 51 ról ziemi uprawnej. Te ostatnie w większości miały rozmiar jednego łanu ${ }^{49}$. Ponieważ przy każdej z tych nieruchomości podana została osoba opłacająca czynsz, możliwe jest zrekonstruowanie struktury majątkowej mieszkańców miasta oraz integracja rozproszonego w przypadku części z nich majątku. Po rekonstrukcji mamy w mieście do czynienia z 271 płatnikami podatku, których można utożsamiać z głowami rodzin, a nie z 340,

\footnotetext{
${ }^{48}$ A. Pawiński, Mazowsze [14], s. 40.

${ }^{49}$ Tamże, s. 41-46.
} 
wyliczonymi przez Pawińskiego. Przy czym wśród tych 271 płatników 165 osób opłacało czynsz wyłącznie z pojedynczej działki miejskiej z domem, 28 osób wyłącznie z ziemi uprawnej (łanów), 5 osób wyłącznie z ogrodów, a 69 osób posiadało więcej niż jedną nieruchomość w różnych konfiguracjach (działki miejskie zabudowane i niezabudowane, ogrody, łany). Dla 4 podatników odtworzenie struktury ich majątku nie było możliwe w związku ze zwolnieniem z opłacania czynszu. Wygląda więc na to, że Pawiński zsumował ze sobą dane o liczbie działek miejskich zabudowanych i niezabudowanych oraz ogrodów bez rekonstruowania struktury własności, pomijając jednocześnie wykazane w inwentarzu łany miejskie. Do tak uzyskanej liczby „rodzin” zastosował przelicznik 4 osób na dom (w tym także dla działek niezabudowanych) i ogród. Jest to sugerowany przez niego w XII tomie Źródet Dziejowych przelicznik dla miast małych, który wynikał z próby dopasowania danych o liczbie domów w miastach powiatu drohickiego do szacunku opartego na założeniu 24 osób na złotówkę szosu. Gdyby w odniesieniu do zrekonstruowanej struktury własności Sierpca zastosować zasady obliczania zaludnienia stosowane przez Pawińskiego dla miast Wielkopolski i Kujaw - uwzględniające w wyliczeniu łany miejskie i średni przelicznik na dom miejski 6 osób - wówczas wypadałoby jego ludność szacować na około 1900 osób:

273 domy $\times 6$ osób $=1638$ osób

28 łanów w formie gospodarstw kmiecych jednołanowych $\times 7$ osób $=196$ osób

23 łany w użytkowaniu posiadaczy działek miejskich $\times 2$ osoby $^{50}=46$ osób

5 ogrodników $\times 4$ osoby $=20$ osób

4 mieszczan libertowanych $\times 6$ osób $=24$ osoby

Tak więc albo wyliczony w oparciu o dane dla województwa łęczyckiego przelicznik 24 osób na złotówkę szosu z jakiegoś powodu wyjątkowo odpowiadał Pawińskiemu, albo w ogóle został stworzony zanim Pawiński przeprowadził jakiekolwiek kalkulacje oparte na źródłach. Wszelkie analizy źródłowe mające teoretycznie zweryfikować słuszność tego przelicznika prowadzone były bowiem w taki sposób, by - poprzez odpowiednio dobrane przeliczniki liczby osób na dom, lub poprzez odpowiednie operowanie danymi źródłowymi - w efekcie uzyskać wynik sugerujący zgodność alternatywnych wyliczeń z szacunkiem opartym na szosie. Pawiński prawdopodobnie świadomie wybrał przelicznik 24 osób na złotówkę szosu spośród dostępnych opcji. Wskazuje na to obecność dwóch różnych wersji wyliczeń liczby ludności miejskiej Wielkopolski

\footnotetext{
${ }^{50}$ Przy założeniu uprawy jak w folwarku bezkmiecym - własnym sprzężajem i z wykorzystaniem stałego personelu w liczbie co najmniej 1 osoby na każde 0,5 łanu.
} 
w XII tomie Źródeł Dziejowych. Pierwsze wyliczenie - umieszczone na stronie 112 - podaje dla poszczególnych województw zaokrąglone kwoty szosu (prawdopodobnie pochodzące z sumariusza 1578 roku) i liczby mieszkańców miast wynikające $\mathrm{z}$ ich przemnożenia przez przelicznik 24 osób na złotówkę. Ogólna liczba ludności miejskiej oszacowana została tu na 170720 osób. Drugie - znajdujące się na stronie 117 - ma formę tabeli zawierającej dla poszczególnych województw szacunki liczby ludności wiejskiej (skopiowane z tabel znajdujących się na stronach 108-109), szacunki liczby ludności miejskiej oraz wyliczenie średniej gęstości zaludnienia na milę kwadratową. W tym wypadku ogólna liczba ludności miejskiej Wielkopolski to tylko 142800 osób, a szacunki dla poszczególnych województw okazują się być niższe o $15-20 \%$ w porównaniu do danych ze strony 112. W tomie XIV Źródet Dziejowych - w celu porównania struktury zaludnienia Małopolski i Wielkopolski - przedrukował Pawiński na stronie 54 tabelę ze strony 117 tomu XII z danymi dla Wielkopolski, przy czym dane o liczbie ludności miejskiej zastąpił tymi pochodzącymi ze strony 112, dającymi ogólną liczbę 170720 osób. Przyznał się przy tym w przypisie, że popełnił „błąd w mnożeniu, w skutek czego iloczyn wypadł mniej więcej 25 tysięcy mniejszym" ${ }^{\prime 1}$. Ten „błąd w mnożeniu” to ponad wszelką wątpliwość efekt zastosowania dla danych o szosie Wielkopolski mnożnika 20 osób na złotówkę, a nie 24 osób, połączonego z operowaniem danymi o wpływach $\mathrm{z}$ szosu $\mathrm{z}$ różnych lat, a nie $\mathrm{z}$ jednego roku. I bynajmniej nie chodzi tu o dane dla lat o najwyższych wpływach. Dane zamieszczone w tabeli 3 wskazują wyraźnie, że w przypadku czterech z siedmiu wyodrębnionych regionów - województw poznańskiego, inowrocławskiego, sieradzkiego i ziemi dobrzyńskiej - zastosowanie mnożnika 20 osób na złotówkę do kwot szosu podanych na stronie 112 daje wyniki dokładnie takie same, jak te umieszczone przez Pawińskiego na stronie 117.

W pozostałych trzech regionach można śmiało założyć, że różnice wynikają nie z zastosowania odmiennych mnożników, ale odmiennych danych o szosie pochodzących z innych lat niż 1578 rok, lub też są efektem dość swobodnego podejścia Pawińskiego do zaokrąglania danych statystycznych. Przykładem jest tutaj samo województwo łęczyckie, dla którego w zestawieniu na stronie 112 podaje on kwotę 650 złotych szosu opłaconego w 1578 roku, podczas gdy na tej samej stronie w tekście podaje kwotę 659 złotych wpływów z szosu w owym roku dla tego województwa. Przyjmując 659 złotych jako podstawę dla przelicznika 20 osób, otrzymamy 13180 mieszkańców miast. W przypadku województw kaliskiego i brzeskiego do wyliczenia na stronie 117 wykorzystane zostały prawdopodobnie dane o wpływach z szosu z innych lat niż deklarowany przez Pawińskiego rok

${ }^{51}$ A. Pawiński, Małopolska [9], s. 55, przypis 1. W odwołaniu do strony z tomu XII mamy tu do czynienia z czeskim błędem, gdyż podana została strona 171. 
Tabela 3. Zestawienie liczby ludności miejskiej i kwot opłaconego szosu podanych przez A. Pawińskiego dla Wielkopolski, z kalkulacją liczby ludności miejskiej dla przelicznika 20 osób na złotówkę szosu

\begin{tabular}{lccc}
\hline Województwo & $\begin{array}{c}\text { Ludność miejska } \\
\text { t. XII, strona } 117\end{array}$ & $\begin{array}{c}\text { Szos }- \text { t. XII, strona } \\
112\end{array}$ & $\begin{array}{c}\text { Ludność miejska }- \\
\text { 20 osób na złoty szosu } \\
\text { ze strony 112 }\end{array}$ \\
\hline Poznańskie & 53000 & 2650 & 53000 \\
Kaliskie & 28000 & 1430 & 28600 \\
Inowrocławskie & 9400 & 470 & 9400 \\
Brzeskie & 9200 & 440 & 8800 \\
Ziemia dobrzyńska & 5000 & 250 & 5000 \\
Łęczyckie & 13200 & 650 & 13000 \\
Sieradzkie & 24400 & 1220 & 24400 \\
\hline
\end{tabular}

Źródło: A. Pawiński, Wielkopolska [4], s. 112, 117; obliczenia własne.

1578. Dla województwa brzeskiego być może pochodziły one z 1569 roku. Wyniosły one wtedy 456 złotych, co przy przeliczniku 20 osób dałoby 9120 osób ludności miejskiej. Przy czym jedno z miast - Sępolno - w owym roku było zwolnione z opłacania szosu w związku z pożarem. Skąd jednak Pawińskiemu przyszedł do głowy pomysł zastosowania przelicznika 20 osób na złotówkę szosu jako alternatywy dla 24 osób przyjętych w wersji ostatecznej? Przyczyną wydaje się być pierwotne wykorzystanie przez niego danych o wpływach z szosu województwa łęczyckiego zawartych w sumariuszu z 1569 roku - tego samego, z którego wykorzystał dane poboru miejskiego tego województwa dla dokonania szacunku liczby ludności miejskiej. Wpływy z szosu wykazane w sumariuszu dla tego województwa wyniosły 757 złotych i 8 groszy, a dla dwóch miast - Orłowa i Strykowa - odnotowano zniżkę na kwotę 26 złotych i 24 groszy w należnym szosie w związku z pożarami ${ }^{52}$. Po zsumowaniu otrzymujemy więc 784 złote i 2 grosze jako kwotę ogólnych należności z szosu województwa łęczyckiego. Jeśli teraz liczbę 15700 osób ludności miejskiej podzielimy przez 784 złote, otrzymamy przelicznik wynoszący 20,03 osoby na złotówkę szosu. To dlatego Pawiński zastosował pierwotnie mnożnik 20 osób i stąd wziął się jego „błąd” w tabeli na stronie 117 tomu XII Źródet Dziejowych. Przelicznik 24 osób, którym zastąpił pierwotnie wyliczony przelicznik 20 osób, był konsekwencją wykorzystania przez niego do ostatecznych wyliczeń danych o wpływach z szosu zawartych w sumariuszu z 1578 roku. Sumariusz 1578 roku musiał mieć w oczach Pawińskiego jedną podstawową przewagę nad sumariuszem 1569 roku, która nie wynikała bynajmniej z najpilniejszej egzekucji podatków w tymże roku. Sumariusz 1578

${ }^{52}$ AGAD, ASK, o. I, ks. 112, k. 66v. 
roku oferował po prostu dane o wpływach z poszczególnych podatków w formie tabelarycznej, zsumowane na poziomie województw. Tymczasem w sumariuszu 1569 roku dane o szosie wymagały zwykle przeliczenia, gdyż często po wymienieniu pełnej listy miast i podaniu opłaconego przez każde z nich szosu wpływy $\mathrm{z}$ tego podatku były sumowane $\mathrm{z}$ wpływami z poboru miejskiego. Przyjąwszy więc dane o szosie z 1578 roku i oszacowawszy liczbę ludności miejskiej dla poszczególnych województw przy zastosowaniu przelicznika 20 osób, Pawiński najpewniej zorientował się, że szacunek ludności województwa łęczyckiego wypada mu znacząco niżej niż w wyliczeniu opartym o pobór miejski. By rozwiązać ten problem, podzielił wyliczoną wcześniej liczbę mieszkańców miast województwa łęczyckiego - 15700 osób - przez kwotę wpływów z szosu w 1578 roku - 659 złotych. Uzyskany wynik - 23,82 - przełożył na ostateczny przelicznik do szacowania liczby ludności miejskiej - 24 osoby na złotówkę szosu.

W słuszności wyliczenia utwierdziło go ponad wszelką wątpliwość to, że oszacowana w ten sposób ludność miejska Wielkopolski stanowiła niemal dokładnie $20 \%$ ogółu ludności regionu. Jednocześnie udział ten był mniejszy niż $22 \%$ z początków XIX wieku i $25 \%$ z połowy XIX wieku notowane w oficjalnych statystykach Królestwa Polskiego tego okresu ${ }^{53}$.

\section{Podsumowanie}

Oczywiście truizmem jest stwierdzenie, że szacowanie liczby ludności miejskiej w oparciu o szos z wykorzystaniem przelicznika 24 osób na jedną złotówkę (czy też jakiegokolwiek innego) nie ma żadnego naukowego uzasadnienia. Już dawno temu Irena Gieysztorowa wskazała bowiem, że podatek ten - jako niemający żadnego związku z demografią miasta - nie powinien być do tego celu wykorzystywany. Zaprezentowana powyżej rekonstrukcja sposobu, w jaki Adolf Pawiński stworzył swój przelicznik demograficzny dla tego podatku, jest tylko argumentem dodatkowym. Jej przeprowadzenie można byłoby uznać w tej sytuacji za bezcelowe, ma ona jednak swój sens. Wynika z niej bowiem, że nie tylko przelicznik liczby osób na złotówkę szosu, ale także liczby osób na dom w przypadku analiz Pawińskiego nie miał w gruncie rzeczy żadnego uzasadnienia źródłowego. Jedynym punktem odniesienia w jego pierwotnej propozycji zakładającej przelicznik 5-7 osób na dom była najprawdopodobniej liczba osób wchodzących w skład gospodarstw kmiecych stwierdzona przez niego na podstawie zachowanych fragmentów poboru pogłównego z 1590 roku. Stosowane przez niego zarówno niższe (4 osoby), jak i wyższe ( 8 osób) przeliczniki miały

\footnotetext{
${ }^{53}$ A. Pawiński, Wielkopolska [4], s. 113.
} 
za zadanie dopasować dane o zaludnieniu wyliczane z szosu do danych o liczbie domów pochodzących z innych źródeł. Jednak o ile przelicznik dla szosu został odrzucony, o tyle przelicznik dla domów został zaakceptowany i wszedł w użycie wśród historyków. Powszechnie zaakceptowany został przelicznik 6 osób na dom, a więc wartość średnia z używanych przez Pawińskiego, a jego popularność trwa do dzisiaj, choć pod wpływem Wstęu do demografii staropolskiej Ireny Gieysztorowej zaczęto także stosować przeliczniki 7 lub 8 osób ${ }^{54}$. Po opublikowaniu tomu Atlasu Historycznego Polski poświęconego województwu sandomierskiemu, w 1993 roku dołączył do nich przelicznik 9 osób na dom, wyliczony w oparciu o zestawienie danych z pogłównego z 1662 roku z podymnym z 1667 roku dla 17 miast powiatu radomskiego, przy czym średnie dla poszczególnych ośrodków wyniosły od 5 do 16 osób na dom ${ }^{55}$. W kolejnych tomach atlasu wykorzystano go do szacowania zaludnienia miast także w innych województwach. Tymczasem nasza dzisiejsza wiedza na temat demografii miast staropolskich wskazuje na niższe w porównaniu do kmieci rozmiary gospodarstw domowych w miastach małych (około 4 osób), a jedynie w dużych - jak Poznań i Kraków - ich rozmiary były zbliżone do gospodarstw kmiecych (5-6 osób) ${ }^{56}$. W związku z tym w chwili obecnej jesteśmy w gruncie rzeczy w tym samym punkcie, w którym znajdował się Pawiński, zanim stworzył przelicznik 24 osób na złotówkę szosu. Nie dysponujemy bowiem żadnym rzetelnym szacunkiem liczby ludności miast dla XVI wieku i na dodatek wiemy, że nie mamy dla tego stulecia żadnego źródła pozwalającego przeprowadzić go w sposób jednolity dla całego terytorium kraju. Jedyne co pozostaje, to wykonanie indywidualnych szacunków dla poszczególnych miast w oparciu o dostępne dla nich źródła różnorakiej proweniencji (co postulowała już wiele lat temu Irena Gieysztorowa) i nadzieja, że dla części ośrodków gdzieś w archiwaliach miejskich zachowały się rejestry podatkowe powstałe w efekcie wewnętrznego ich opodatkowania na potrzeby uiszczenia szosu królewskiego.

\footnotetext{
${ }^{54}$ Przy czym trwałość przelicznika 6 osób na dom jest wręcz zadziwiająca. Pojawia się on bowiem nie tylko w pracach starszych, jak choćby przywoływana wyżej praca Stanisława Pazyry (Studia z dziejów [25)] czy też publikacjach powstałych przed ukazaniem się Wstępu do demografii staropolskiej, ale także i w XXI wieku. Patrz na przykład: Radom. Szkice z dziejów miasta, red. Jęrzej Jędrzejewicz, Warszawa 1961, s. 15; Zenon Guldon, Zaludnienie miast kujawskich w XVI i pierwszej połowie XVII wieku, „Prace Komisji Historii Bydgoskiego Towarzystwa Naukowego”, PWN, Łódź 1963, s. 55; Janusz Szczepański, Miasto Gostynin w latach 1462-1793, [w:] Dzieje Gostynina od XI do XXI wieku, red. Barbara Konarska-Pabianicka, Gostynin 2010, s. 136; Brzeziny. Dzieje miasta, red. Kazimierz Bodziak, Łódź-Brzeziny 1997, s. 58; Feliks Kiryk, Żarnowiec, [w:] Dzieje Olkusza i regionu olkuskiego, t. 1, red. Feliks Kiryk, Ryszard Kołodziejczyk, WarszawaKraków 1978, s. 424-425.

${ }^{55}$ A. Dunin-Wąsowicz, Charakter i wielkość osiedli [32], s. 81, przypis 51.

${ }^{56}$ C. Kuklo, Wielkość i struktura [36], s. 171.
} 
W znacznie lepszej sytuacji jesteśmy, jeśli chodzi o przeliczniki dla ludności wiejskiej. W porównaniu z przelicznikiem dla szosu, system zaproponowany przez Pawińskiego dla ludności wiejskiej okazał się być w miarę wiarygodny i przez to trwały. Uwagi krytyczne zgłaszane przez Władysława Czerkawskiego czy też Irenę Gieysztorową miały na celu przede wszystkim wprowadzenie zmian eliminujących z szacunku Pawińskiego wyraźnie widoczne znamiona tworzenia go na potrzeby prowadzenia szacunku w oparciu o sumariusze podatkowe oraz braku u schyłku XIX wieku jakichkolwiek badań nad demografią rodziny staropolskiej. Skutkiem korzystania z sumariuszy było na przykład stosowanie przez Pawińskiego jednolitego przelicznika 4 osób na rodzinę zarówno ogrodniczą, jak i komorniczą, mimo że dane z pogłównego 1590 roku sugerują konieczność stosowania zróżnicowanych przeliczników. W sumariuszach dla 1569 roku, które w tabelach Pawińskiego figurują jako dane dla roku 1571, obie te grupy ludności wiejskiej zostały bowiem w przypadku województwa sieradzkiego zsumowane razem i to dlatego zastosował on wspólny dla nich przelicznik. Także jednolity przelicznik 5 osób na rodzinę dla przekupniów, rzemieślników wiejskich, rybaków i innych kategorii niekmiecej ludności wiejskiej był efektem częstego sumowania tych grup w sumariuszach. Założenie, że na jeden młyn składały się średnio trzy koła młyńskie, było natomiast skutkiem operowania przez sumariusze jedynie zbiorczymi danymi o łącznej liczbie kół. Tymczasem w rejestrach podstawowych zazwyczaj mamy do czynienia z informacją zarówno o liczbie młynów, jak też liczbie znajdujących się w każdym z nich kół, wskazującą na zdecydowaną przewagę liczbową urządzeń o jednym kole, a więc znacznie większą liczbę istniejących jednostek gospodarczych niż zakładana przez Pawińskiego.

Brak w końcu XIX wieku badań demograficznych widoczny jest w szacunku Pawińskiego przede wszystkim w mechanicznym przenoszeniu zaludnienia gospodarstwa kmiecego - szacowanego na 5-6 osób w oparciu o fragmentarycznie zachowany spis pogłównego z 1590 roku - na większość innych wyodrębnianych grup społecznych: młynarzy, karczmarzy, gorzelników, przekupniów, a także na rodzinę szlachecką. Pawiński bezrefleksyjnie tu założył, że każdorazowe pojawienie się w rejestrach podatkowych takich elementów infrastruktury wiejskiej jak młyn, karczma, gorzelnia czy też szynk gorzałki automatycznie oznacza funkcjonowanie odrębnej jednostki rodzinno-gospodarczej. Tymczasem nie jest to bynajmniej oczywiste, zwłaszcza w przypadku szynków i instalacji gorzelnianych. Nie musiały one bowiem wcale być jednostkami gospodarczymi przekładającymi się automatycznie na funkcjonowanie odrębnych kategorii ludności, jak szynkarze czy też gorzelnicy, ale mogły funkcjonować jako części składowe gospodarstw karczmarzy czy też kmieci.

Największy potencjał w zakresie zmiany szacunku zaludnienia Polski w końcu XVI wieku kryje się jednak w przelicznikach dla folwarków zarówno szlachty 
kmiecej, jak i bezkmiecej, oraz w przelicznikach liczby gospodarstw kmiecych na opodatkowany łan i towarzyszących im przelicznikach liczby osób przypadających na gospodarstwo kmiece. Utożsamienie przez Pawińskiego liczby wsi z liczbą istniejących folwarków szlachty kmiecej (a więc założenie średniego nasycenia nimi $w$ wysokości jednego folwarku na wieś) nie wynikało $\mathrm{z}$ analizy statystycznej danych zawartych w rejestrach poborowych, ale z ogólnego wrażenia, jakie odniósł badacz w trakcie ich lektury. Stwierdził on bowiem dominowanie w przypadku Wielkopolski jednowioskowych majątków szlacheckich ${ }^{57}$. Jednocześnie założenie przeciętnej obecności 5-6 osób czeladzi na folwark nie było wynikiem jakiejkolwiek refleksji nad zapotrzebowaniem na pracę najemną ze strony gospodarstwa folwarcznego i gospodarstwa rodzinnego szlachty, ale efektem teoretycznych, subiektywnych odczuć autora ${ }^{58}$. W przypadku demografii samej rodziny szlacheckiej koniecznością jest stosowanie zróżnicowanych przeliczników uwzględniających zarówno wielkość majątku szlacheckiego, jak i jego geograficzną lokalizację $e^{59}$. Konieczne jest także wprowadzenie merytorycznie uzasadnionego szacunku liczby folwarków i zróżnicowanie w kalkulacji poziomu ich nasycenia personelem zależnie od rozmiarów majątku właściciela, jak też od lokalnych uwarunkowań gospodarczych. Do takiego wniosku skłaniają dotychczasowe ustalenia poczynione w tym zakresie przez Andrzeja Wyczańskiego i Marcina Kamlera. Kalkulacje tego pierwszego w odniesieniu do zapotrzebowania na stały personel ze strony folwarków szlacheckich wskazują na konieczność zatrudniania w przeciętnym folwarku (3,5-4,0 lanu) od 2 do 4 osób stałego personelu zajmującego się wyłącznie uprawą ziemi - a więc ratajów i parobków - bez uwzględniania służby domowej ${ }^{60}$. Kluczowe znaczenie ma w tym wypadku rozmiar dostępnej pańszczyzny sprzężajnej, powodujący regionalne zróżnicowanie w tym zakresie, przy generalnej tendencji do rekompensowania niedoboru pańszczyzny sprzężajnej zatrudnianiem dodatkowego personelu stałego w folwarkach. Z kolei w przypadku badań drugiego ze wspomnianych autorów, jego ustalenia dla Wielkopolski sugerują relatywnie wyższe nasycenie personelem stałym folwarków małych o areale do 2 łanów i bardzo skromną obecność personelu stałego w folwarkach dużych o areale ponad 11 łanów ${ }^{61}$. Jak się wydaje, badania w tym właśnie zakresie - pozwalające na ustalenie związków zachodzących między liczbą stałego personelu a lokalizacją geograficzną folwarku, jego areałem i statu-

${ }^{57}$ A. Pawiński, Wielkopolska [4], s. 141.

${ }^{58}$ Tamże, s. 106.

${ }^{59}$ C. Kuklo, Wielkość i struktura [36], s. 169-170.

${ }^{60}$ Andrzej Wyczański, Studia nad folwarkiem szlacheckim w Polsce 1500-1580, Warszawa 1960, s. 131.

${ }^{61}$ Marcin Kamler, Folwark szlachecki w Wielkopolsce w latach 1580-1655, Warszawa 1976, s. $50-62$. 
sem majątkowym właściciela folwarku - są kluczem do uzyskania wiarygodnych, zregionalizowanych przeliczników. Ten sam problem dotyczy majątków szlachty bezkmiecej. Zastosowany w odniesieniu do niej przez Pawińskiego jednolitego w skali kraju przelicznika 11 osób na łan było w gruncie rzeczy mechanicznym przeniesieniem ustaleń poczynionych wcześniej dla gospodarstw kmiecych i nie towarzyszyła temu żadna analiza regionalnego zróżnicowania jej struktury majątkowej, ekonomicznych realiów działalności gospodarczej i wynikającego $\mathrm{z}$ tego zmiennego zapotrzebowaniem na służbę.

W przypadku ludności kmiecej zgłaszany swego czasu przez Irenę Gieysztorową postulat zróżnicowania na poziomie powiatów przelicznika liczby gospodarstw kmiecych na jeden opodatkowany łan jest niewykonalny. Wynika to $\mathrm{z}$ braku dla wielu jednostek terytorialnych zachowanych podstawowych rejestrów podatkowych z 1552 roku. Ale dla większości terenu Królestwa Polskiego przeliczniki takie mamy na poziomie województw, dzięki zachowaniu sumariuszy podatkowych z lat 1552 i $1563^{62}$. Największy potencjał zmian w porównaniu $\mathrm{z}$ dotychczasowymi szacunkami tkwi nie tylko w precyzyjnym ustaleniu różnic w zakresie liczby osób w rodzinie biologicznej w zależności od wielkości majątku kmiecego, ale także w zróżnicowanej liczbie osób wchodzących w skład gospodarstwa kmiecego wynikającej ze zmiennego zapotrzebowania na służbę zależnie od wielkości jego areału, jak i zapotrzebowania na pańszczyznę ze strony folwarku.

The Past of the Demographic Conversion Factors for the Middle Ages Tax Sources

\section{Summary}

The article presents the demographic conversion factors that have been used for a hundred years in the research on Poland's population of the second half of the $16^{\text {th }}$ century. The forerunner of research in that sphere and the editor of basic sources was Adolf Pawiński; his proposal for the conversion factors was criticised by many researchers, among others Włodzimierz Czerkawski, Witold Kula, Irena Gieysztorowa. After a hundred-year discussion it may be said that «Źródła Dziejowe» and the method of computing urban populations used by Pawiński are not the recommended tools; similarly, demographic conversion factors for rural populations should be modified or specified.

Keywords: population, the Kingdom of Poland, demographic conversion factors, urban population, rural population, Adolf Pawiński

\footnotetext{
${ }^{62}$ Krzysztof Boroda, O przydatności rejestrów poborowych z XVI wieku w badaniach demograficznych, „Przeszłość Demograficzna Polski” 2014 (33), s. 29-33.
} 